\title{
Correlation of Mean Nuclear Major Diameter Based Nuclear Morphometry Assessed by Image Analysis System and Fuhrman Nuclear Grading with Clinicopathologic Prognostic Parameters in Renal Cell Carcinoma
}

\author{
Zeliha Esin Celik ${ }^{1}$, Mustafa Cihat Avunduk ${ }^{2}$
}

\begin{abstract}
${ }^{1}$ Assistant Professor, Selcuk University Faculty of Medicine, Department of Pathology, Konya, TURKEY
\end{abstract}

2Professor, Necmettin Erbakan University Meram Faculty of Medicine, Department of Pathology, Konya, TURKEY

Eur J Basic Med Sci 2013;3(3): 44-49

Received: 25-04-2013

Accepted: 23-10-2013

Correspondence (Yazışma Adresi):

Zeliha Esin CELIK

Selcuk University Faculty of Medicine, Department of Pathology, Konya, TURKEY

Telephone: 0090 -533-661 1633

Fax: 0090-332-2244807

e-mail: dresincelik@hotmail.com

\begin{abstract}
To evaluate mean nuclear major diameter (MNMjD) by using an image analysis system and to compare MNMjD-based nuclear morphometry with Fuhrman grading system in terms of correlation with clinicopathologic prognostic parameters in renal cell carcinoma (RCC). Ninety cases diagnosed as RCC were examined in terms of Furhman nuclear grade, histological subtype, renal capsular invasion, perinephric fat invasion, and renal vein and/or ureter invasion. MNMjD was assessed using a computer-assisted image analysis system on histological sections. In addition to the classic system, Fuhrman nuclear grades were examined by dividing into low grade and high grade groups. The correlation between parameters was evaluated statistically. Nuclear morphometry based on MNMjD has higher correlation with clinicopathologic prognostic parameters compared with the Fuhrman nuclear grading system, including individual grades and low grade and high grade groups. Nuclear morphometry is a valuable method in RCC grading and can be used as an alternative system considering its correlation with clinicopathologic prognostic parameters.
\end{abstract}

Key Words: Renal cell carcinoma, nuclear morphometry, prognosis, image analysis

Renal Hücreli Karsinomda Görüntü Analizi Sistemi ile Değerlendirilen Ortalama Major Çekirdek Çapına Dayalı Çekirdek Morfometrisi ve Fuhrman Çekirdek Derecelendirmesinin Klinikopatolojik Prognostik Parametrelerle Korelasyonu

\section{ÖZET}

Renal hücreli karsinomlarda (RHK) görüntü analizi sistemi kullanılarak ortalama major çekirdek çapının değerlendirilmesi ve buna dayalı çekirdek morfometrisinin klinikopatolojik prognostik parametrelerle korelasyonu açısından Fuhrman nükleer derecelendirme sistemi ile karșılaștırılması amaçlandı. RCC tanılı 90 hasta ilk aşamada, Fuhrman çekirdek derecesi, histolojik alt tip, böbrek kapsül invazyonu, perirenal yağlı doku invazyonu ve renal ven/ üreter invazyonu yönünden incelenmiștir. Bilgisayar bağlantılı görüntü analiz sistemi kullanılarak olguların histolojik kesitlerinde ortalama major çekirdek çapları 
hesaplanmıştır. Fuhrman çekirdek dereceleri klasik sisteme ek olarak düșük dereceli ve yüksek dereceli gruplara ayrılarak da incelenmiștir. Parametreler arasındaki ilişki istatistiksel olarak değerlendirilmiştir. Ortalama major çekirdek çapına dayalı çekirdek morfometrisi, Fuhrman çekirdek derecelendirme sisteminin hem ayrı ayrı hem de düșük ve yüksek dereceli gruplarına klyasla, RHK larda prognostik parametrelerle daha güçlü bir korelasyona sahiptir. RHK derecelendirmesinde çekirdek morfometrisi değerli bir metoddur ve klinikopatolojik prognostik parametrelerle korelasyonu göz önüne alındığında alternatif bir sistem olarak kullanılabilir.

Anahtar Kelimeler: Renal hücreli karsinom, çekirdek morfometrisi, prognoz, görüntü analizi

\section{INTRODUCTION}

Renal cell carcinoma (RCC), which ranks 3rd after prostate and bladder carcinomas among urinary system malignancies, constitutes 2-3\% of adult malignancies (1-3). This rate is higher in developed countries (3). Surgery is the only curative treatment modality for RCC, which has an unpredictable prognosis with a tendency to recur or cause death many years after initial treatment $(4,5)$.

In many studies, several clinical and pathologic parameters that affect prognosis have been reported. Prognostic factors are useful in determining the clinical and biological behavior of RCC. Parameters of prognostic value are tumor stage, nuclear grade, histological subtype, clinical and laboratory findings of the patient and molecules defined in studies based on gene sequence examining variable expressions of thousands of genes. The relation of these parameters with prognosis has been discussed in many studies, and various results have been reported (69). Recently, several studies on the relation of morphometric parameters with prognosis have been carried out. The quantitative assessment of nuclear morphometry is possible with computer imaging systems, providing a useful and reproducible method for predicting prognosis for many cancers (4). Significant correlation between nuclear morphometry and prognosis of RCC has been reported $(4,10,11)$. In the present study, we aimed to evaluate the mean nuclear major diameter (MNMjD), a nuclear morphometric method, by using an image analysis system and to compare MNMjD based nuclear morphometry with Fuhrman grading system in terms of correlation with clinicopathologic prognostic parameters in RCC.

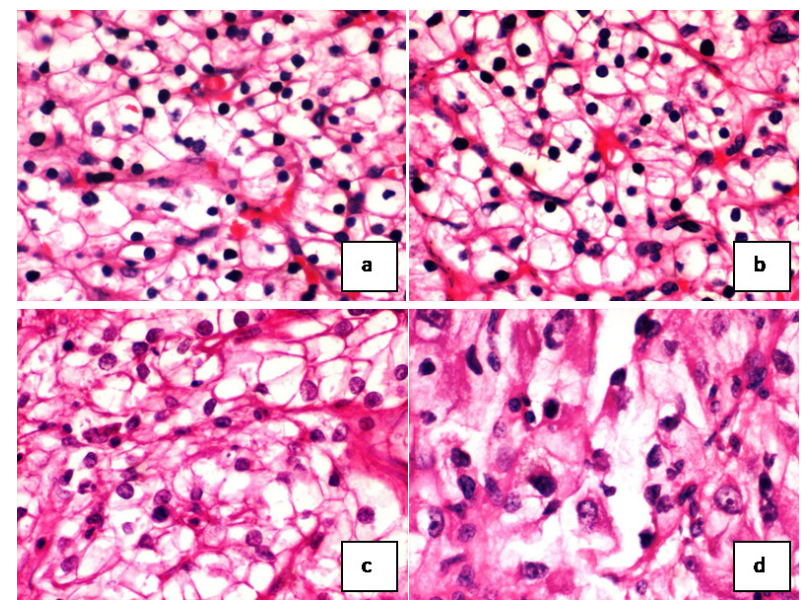

Figure 1. Tumor samples for Fuhrman grade I (a), grade II (b), grade III (c) and grade IV (d). (Hematoxylin eosineX100)

\section{MATERIALS AND METHODS}

Ninety cases with RCC who underwent partial or radical nephrectomy at our institution between 2006-2010 were included into our study. The hematoxylin-eosin stained slides with best of the tumor samples were chosen for each case from the pathology archive and evaluated by light microscopy by a pathologist (E.C.) with regards to histological subtype (clear cell, chromophobe, papillary, sarcomatoid differentiated), Fuhrman nuclear grade (Figure 1), perinephric fat invasion, renal vein and/or ureter invasion and renal capsule invasion. At this stage, 5 cases of clear cell tumors and 2 cases of chromophobe tumors showing sarcomatoid differentiation were considered as a separate group, referred to as sarcomatoid differentiation showing group among the different histological subtypes. In addition to the classic system, Fuhrman nuclear grades have been examined by dividing the samples into low grade and high grade groups.

The same slides were examined histomorphometrically with an image analysis system. For each specimen, the tumor area was photographed using a Pixera 150ES-CU photograph attachment. The photograph of the Nikon objective micrometer microscope slide (MBM11100. Japan) was also taken during the procedure. All photographs were then transferred into PC environment and analyzed by using NEO Image Analysis Program v.2.0 (12). The length was calibrated by comparing the photograph of a specimen with the photograph of the Nikon micrometer 


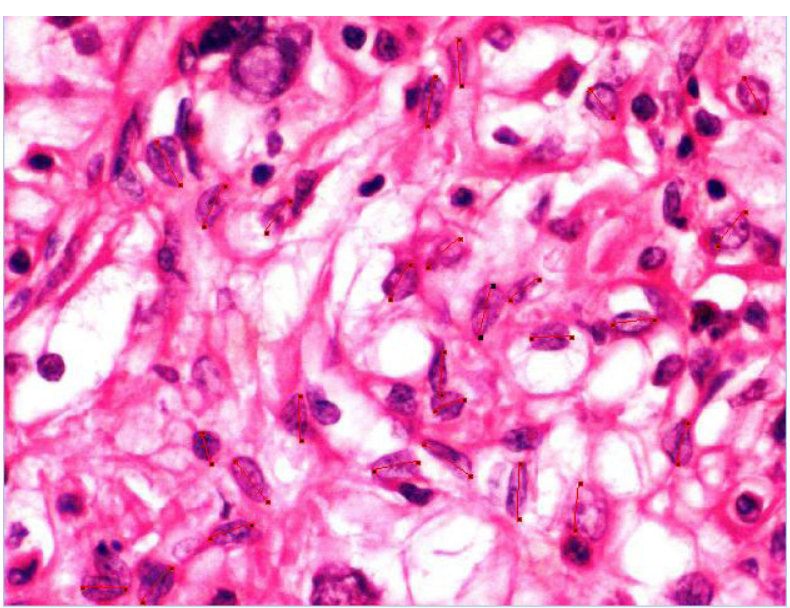

Figure 2. This photograph taken on image analysis programme shows major diameter of some tumor cell nuclei marked manually at unit area. (Hematoxylin eosine X100)

microscope slide, taken under the same magnification. Following length calibration, the evaluated area (unit area) was calculated with the image analysis program and determined as $0.08 \mathrm{~mm} 2$. Major nuclear diameters of approximately 50 tumor cells at unit area were manually marked on the photograph of each case using image analysis programme (Figure 2). The means and standard deviations of these diameters were then automatically calculated by the same programme. Damaged cells were not evaluated. The reader was masked to the origin of the specimen. All statistical tests were performed by using SPSS (Statistical Package for Social Sciences) for Windows on PC. One-way ANOVA test with the post hoc test of Tukey HSD were used to reveal the correlation between nuclear morphometry and Furhman nuclear grading. Independent sample t-test was added to reveal the correlation between nuclear morphometry and clinicopathologic prognostic parameters. Chi-square test was used to reveal the correlation between Fuhrman nuclear grading and clinicopathologic prognostic parameters. All calculated $P$ values were two-tailed, and $p<0.05$ was considered as indicating statistical significance.

\section{RESULTS}

Table 1 shows the correlation of Fuhrman nuclear grading with clinicopathologic prognostic parameters. Fuhrman nuclear grading was significantly related to the histologic subtype $(p=0.035)$. Most sarcomatoid differentiated tumors were identified as Fuhrman grade IV and papillary tumors were identified as grade III. Perinephric fat invasion was higher in grade IV tumors compared to the other tumor grades $(p=0.001)$. Renal vein and/or ureter invasion $(p>0.05)$ and renal capsule invasion $(p>0.05)$ were not correlated with Fuhrman nuclear grading. However, dividing the cases between low grade (grade 1 and grade 2 ) and high grade (grade 3 and grade 4) groups in the Fuhrman grading system revealed that high grade tumors had greater renal capsule invasion in comparison to low grade tumors $(\mathrm{p}=0.044)$. The low grade and high grade groups have not revealed a statistically significant relationship with histologic subtypes $(p>0.05)$; however,

Table 1. Correlation of Fuhrman nuclear grading with clinicopathologic prognostic parameters

\begin{tabular}{|c|c|c|c|c|c|c|c|}
\hline \multirow[b]{2}{*}{ Number of cases (\%) } & \multirow[b]{2}{*}{ Total } & \multicolumn{4}{|c|}{ Fuhrman Nuclear Grade } & \multirow{2}{*}{$\begin{array}{l}\text { Low Grade Group } \\
\text { (Grade I+II) }\end{array}$} & \multirow{2}{*}{$\begin{array}{l}\text { High Grade Group } \\
\text { (Grade III+IV) }\end{array}$} \\
\hline & & 1 & II & III & IV & & \\
\hline \multicolumn{8}{|l|}{ Histologic subtype } \\
\hline Clear cell & $56(62.2)$ & $3(100)$ & $13(86.7)$ & $22(57.9)$ & $18(52.9)$ & $16(88.9)$ & $40(55.6)$ \\
\hline Chromophobe & $19(21.1)$ & $0(0)$ & $2(13.3)$ & $8(21.1)$ & $9(26.5)$ & $2(11.1)$ & $17(23.6)$ \\
\hline Papillary & $8(8.9)$ & $0(0)$ & $0(0)$ & $7(18.4)$ & $1(2.6)$ & $0(0)$ & $8(11.1)$ \\
\hline Sarcomatoid diff. & $7(7.8)$ & $0(0)$ & $0(0)$ & $1(2.6)$ & $6(17.6)$ & $0(0)$ & $7(9.7)$ \\
\hline \multicolumn{8}{|l|}{ Perinephric fat invasion } \\
\hline Positive & $18(20)$ & $0(0)$ & $0(0)$ & 4 (10.5) & $14(41.2)$ & $0(0)$ & $18(25)$ \\
\hline Negative & $72(80)$ & $3(100)$ & 15(100) & $34(89.5)$ & $20(58.8)$ & $18(100)$ & $54(75)$ \\
\hline \multicolumn{8}{|l|}{ Ureter/Renal vein invasion } \\
\hline Positive & $5(5.6)$ & $0(0)$ & $0(0)$ & $1(2.6)$ & $4(11.8)$ & $0(0)$ & $5(6.9)$ \\
\hline Negative & $85(94.4)$ & $3(100)$ & $15(100)$ & $37(97.4)$ & $30(88.2)$ & $18(100)$ & $67(93.1)$ \\
\hline \multicolumn{8}{|l|}{ Renal capsule invasion } \\
\hline Positive & $49(54.4)$ & $0(0)$ & $6(40)$ & $20(52.6)$ & $23(67.6)$ & $6(33.3)$ & 43(59.7) \\
\hline Negative & $41(45.6)$ & $3(100)$ & $9(60)$ & $18(47.4)$ & $11(32.4)$ & $12(66.7)$ & $29(40.3)$ \\
\hline
\end{tabular}


Table 2. Correlation of histomorphometric data with clinicopathologic prognostic parameters

\begin{tabular}{cll}
\hline & $\mathrm{N}(\%)$ & MNMjD $(\mathrm{sd})(\mu \mathrm{m})$ \\
\hline Histologic subtype & & \\
Clear cell & $56(62.2)$ & $8.55(1.4)$ \\
Chromophobe & $19(21.1)$ & $8.49(0.95)$ \\
Papillary & $8(8.9)$ & $8.31(0.62)$ \\
Sarcomatoid diff. & $7(7.8)$ & $10.1(1.4)$ \\
I & & \\
II & $3(3.3)$ & $6.44(0.77)$ \\
III & $15(16.7)$ & $7.33(0.59)$ \\
IV & $38(42.2)$ & $8.7(0.86)$ \\
Fuhrman Nuclear Grade & $34(37.8)$ & $9.33(1.41)$ \\
Positive & $18(20)$ & $9.3(1.45)$ \\
Negative & $72(80)$ & $8.47(1.24)$ \\
Perinephric fat invasion & & $8.95(1.35)$ \\
Positive & $5(5.6)$ & $8.62(1.32)$ \\
Negative & $85(94.4)$ & $8.96(1.38)$ \\
Ureter/Renal vein invasion & & \\
Pesitive & $49(54.4)$ & \\
Renal capsule invasion & $41(45.6)$ & $(1.13)$ \\
Negative &
\end{tabular}

$\mathrm{N}$ : Number of cases; MNMjD: Mean nuclear major diameter; Sd: Standard deviation

chromophobe, papillary and sarcomatoid differentiated tumors were identified more within the high grade rather than the low grade group. High grade group tumors demonstrated an increased perinephric fat invasion $(\mathrm{p}=0.018)$, as previously indentified in the individual grades. Renal vein and/or ureter invasion were identified only in high grade group tumors; however the difference between high grade and low grade group tumors were found not to be statistically significant $(p>0.05)$.

We have identified a significant correlation between MNMjD based nuclear morphometry and certain clinicopathologic prognostic parameters listed in Table 2. Sarcomatoid differentiated tumors have higher MNMjD than clear cell $(p=0.014)$, chromophobe $(p=0.024)$ and papillary $(p=0.035)$ tumors. MNMjD observed to be higher in tumors with perinephric fat invasion $(\mathrm{p}=0.017)$ and renal capsule invasion $(p=0.009)$ in comparison to tumors which are not positive for invasion. Positive renal vein and/or ureter invasion was not related with MNMjD ( $p>0.05)$. MNMjD also demonstrated a significant correlation with Fuhrman nuclear grades $(p=0.00)$. We determined that MNMjD values increased in parallel to the Fuhrman nuclear grade. Statistically significant differences were identified between grade I and grade III $(\mathrm{p}=0.004)$, grade I and grade IV $(\mathrm{p}=0.00)$, grade II and grade III $(\mathrm{p}=0.00)$, grade II and grade IV $(\mathrm{p}=0.00)$ tumors.

\section{DISCUSSION}

In RCC, the most important prognostic parameters that provide an opinion regarding the potential clinical and biological behavior of the tumor are the tumor stage and grade. Histologic subtype, renal capsule invasion, perinephric fat invasion, ureter and renal vein invasion constitute other significant clinicopathologic predictors of prognosis. The relationship between these parameters and prognosis as well as the survey of patients with RCC has been discussed in numerous studies until now. The most commonly used nuclear grading system for RCC today is that Fuhrman et al. $(6,13)$ had suggested. Many studies have demonstrated the independent prognostic significance of nuclear grading with regards to long-term survival. Nuclear grading was suggested as a useful prognostic indicator for disease at any stage. Skinner et al. (14) had identified a complete correlation between nuclear grading and survival. Uno et al. (15) have nuclear grading to be a significant factor for the prediction of post-surgery survival in their study with 482 patients with RCC. Significant relationship was also observed in many studies between nuclear grading and the spread of the disease, lymph node involvement, perinephric fat invasion and renal capsule invasion (16-19).

Although certain studies in the literature suggest that Fuhrman nuclear grading is significantly related with survival, other studies appear to contradict these observations. Delahunt et al. (20) reported that neither Fuhrman grading nor any of the components of this grading system are useful prognostic indicators of chromophobe type RCCs. Lang et al. (13) performed a multi-centered study to assess inter-observer agreement between three pathologists using the Fuhrman grading system and observed a low-to-moderate agreement. They explained the level of moderate agreement as being due to the heterogeneity of RCCs and their cell composition with different grades in the same tumor. They concluded that collapsing the Fuhrman grading system into a low-grade (Grade 1-2) group and a high-grade (Grade 3-4) group improves the inter-observer agreement without causing a significant loss of information regarding survival. These studies have described the issues encountered with the Fuhrman nuclear grading system with regards to reproducibility, inter-observer variability and objectivity. The need for a better standardization of nuclear criteria to improve inter-observer reproducibility in RCC grading 
has necessitated the development of grading systems with greater objectivity (21). Nuclear morphometry is the most commonly used system for this purpose. In recent years, nuclear morphometry was applied to kidney, bladder, prostate, breast and endometrium carcinomas in order to determine prognostic significance. Moreover, it has been reported that nuclear morphometry might be used for differential diagnosis of benign and malignant lesions and RCC subtypes (22). Paner et al. (23) suggested the use of chromophobe tumor grade, based on the assessment of geographic nuclear crowding, and of anaplasia for chromophobe RCC grading as an alternative system. They emphasized that the chromophobe tumor grading system provides superior prognostic value in comparison to the Fuhrman nuclear grade in chromophobe RCC. In their study performed to compare morphometric index with Fuhrman nuclear grading, Montironi et al. (24) concluded that the morphometric index might be useful in supplementing the pathologist's grading of RCC. Nowadays, with the development of advanced computer systems and programs, many different parameters including mean nuclear area (MNA), elipticity, volume (MNV), perimeter (MNP), major diameter (MNMjD), minor diameter (MNMnD) and form factor (MNFF) are becoming increasingly common $(4,5,24)$. Among these, MNA is commonly evaluated parameter. Tosi et al. (25) determined that patients with MNA values lower than $32 \mu \mathrm{m}^{2}$ had significantly better prognosis and survival compared to patients with higher values. In a similar study, Ozer et al. (4) identified high risk of tumor progression for patients with MNA values higher than $150 \mu \mathrm{m}^{2}$. They also revealed that higher values of MNA, MNP, MNMjD and MNMnD were significantly related with sarcomatoid histology, advanced tumor stage, higher nuclear grade and proliferative activity.

In our study, we have determined that the Fuhrman nuclear grading is related with histologic subtype and perinephric fat invasion; however, in contrast to Bretheau et al. (16). and Klatte et al. (19) studies, no relation was identified with renal vein and/or ureter invasion and renal capsule invasion. We have also determined that dividing the cases into low grade (grade 1 and grade 2 ) and high grade (grade 3 and grade 4) groups in the Fuhrman grading system, as Lang et al. (13) have in their study, engendered significant correlation with some clinicopathologic prognostic parameters, including perinephric fat invasion and renal capsule invasion. However, in contrast to individual Fuhrman grades, low grade and high grade groups have not revealed any relationship with histologic subtype. During the study, we have performed an evaluation of MNMjD among the histomorphometric parameters and obtained results similar to those of Ozer et al. (4). We have observed that higher MNMjD values are correlated with sarcomatoid morphology, perinephric fat and renal capsule invasion positivity. In addition, we identified that the mean nuclear diameter increased in parallel with the Fuhrman nuclear grade. In other words, MNMjD was correlated with the Fuhrman nuclear grade.

When compared with the Fuhrman nuclear grading system, both with the individual grades as well as the low and high grade groups, nuclear morphometry based on MNMjD had a higher correlation with clinicopathologic prognostic parameters. In conclusion, in the light of the existing literature, nuclear morphometry is a valuable method for RCC grading that can be used as an alternative system considering its correlation with clinicopathologic prognostic parameters.

\section{REFERENCES}

1. Landis SH, Murray T, Bolden S et al. Cancer statistics. CA Cancer J. Clin 1999; 49: 8-31.

2. Laber DA. Risk factors, classification and staging of renal cell cancer. Med Oncol 2006; 23: 443-54.

3. Eble JN, Sauter G, Epstein JI et al. World Health Organization Classification of Tumours, Pathology and Genetics of Tumours of the Urinary System and Male Genital Organs, 4th ed. Lyon: IARC Press, 2004; 10: 43.

4. Ozer E, Yorukoglu K, Sagol O et al. Prognostic significance of nuclear morphometry in renal cell carcinoma. BJU Int 2002; 90: 20-5.

5. Yorukoglu K, Aktas S, Güler C et al. Volume-weighted mean nuclear volume in renal cell carcinoma. Urology 1998; 52: 44-7.

6. Fuhrman SA, Lasky LC, Limas C. Prognostic significance of morphologic parameters in renal cell carcinoma. Am J Surg Pathol 1982; 6: 655-63.

7. Kattan MW, Reuter V, Motzer RJ et al. A postoperative prognostic nomogram for renal cell carcinoma. J Urol 2001; 166: 63-7.

8. Zisman A, Pantuk AJ, Dorey F. Improved prognostication of renal cell carcinoma using an integrated staging system. $J$ Clin Oncol 2001; 19:1 649-57.

9. Maldazys JD, De Kernion JB. Prognostic factors in metastatic renal carcinoma. J Urol 1986; 136(2): 376-9. 
10. Pascual D, Borque A. Epidemiology of kidney cancer. Adv Urol 2008; 782381

11. Godley PA, Ataga KI. Renal cell carcinoma. Curr Opin Oncol 2000; $12: 260-4$

12. Işik $H$, Sezgin E, Avunduk MC. A new software program for pathological data analysis. Comput Biol Med 2010; 40(8): 715-22.

13. Lang $H$, Lindner $V$, de Fromont $M$ et al. Multicenter determination of optimal interobserver agreement using the Fuhrman grading system for renal cell carcinoma: Assessment of 241 patients with > 15-year follow-up. Cancer 2005; 103(3): 625-9.

14. Skinner DG, Calvin RB, Vermillion CD et al. Diagnosis and management of renal cell carcinoma: A clinical and pathologic study of 309 cases. Cancer 1971; 28: 1165-77.

15. Uno M, Fujimoto $Y$, Takada $T$ et al. Prognostic factors for survival of patients after curative surgery for renal cell carcinoma: Multivariate analysis of 482 cases. Int J Clin Oncol 2004; 9(6): 510-4.

16. Bretheau D, Lechevallier $E$, de Fromont $M$ et al. Prognostic value of nuclear grade of renal cell carcinoma. Cancer 1995; 76(12): 2543-9.

17. Minervini $R$, Minervini A, Fontana $N$ et al. Evaluation of the 1997 tumor, nodes and metastases classification of renal cell carcinoma: Experience in 172 patients. BJU Int 2000; 86(3): 199-202.
18. Giberti C, Oneto F, Martorana G et al. Radical nephrectomy for renal cell carcinoma: Long-term results and prognostic factors on a series of 328 cases. Eur Urol 1997; 31: 40-8

19. Klatte T, Chung J, Leppert JT et al. Prognostic relevance of capsular involvement and collecting system invasion in stage I and II renal cell carcinoma. BJU Int 2007; 99(4): 821-4.

20. Delahunt B, Sika-Paotonu D, Bethwaite PB et al. Fuhrman grading is not appropriate for chromophobe renal cell carcinoma. Am J Surg Pathol 2007; 31(6): 957-60.

21. Novara G, Martignoni G, Artibani W et al. Grading systems in renal cell carcinoma. J Urol 2007; 177: 430-6

22. Artacho-Pérula E, Roldán-Villalobos R, Martínez-Cuevas JF. Value of volume weighted mean nuclear volume in grading and prognosis of renal cell carcinoma. J Clin Pathol 1994; 47(4): 324-8.

23. Paner GP, Amin MB, Alvarado-Cabrero l et al. A novel tumor grading scheme for chromophobe renal cell carcinoma: prognostic utility and comparison with Fuhrman nuclear grade. Am J Surg Pathol 2010; 34(9): 1233-40.

24. Montironi $R$, Santinelli A, Pomante R et al. Morphometric index of adult renal cell carcinoma. Comparison with the Fuhrman grading system. Virchows Arch 2000; 437(1): 82-9.

25. Tosi P, Luzi P, Baak JP et al. Nuclear morphometry as an important prognostic factor in stage I renal cell carcinoma. Cancer 1986; 58: 2512-8. 